\title{
Generation of Bioenergy from Sewage Using Dual Chamber Microbial Fuel Cell
}

\section{Anand Parkash ${ }^{\star}$}

Department of Chemical Engineering, Mehran University of Engineering \& Technology, Jamshoro, Pakistan

\begin{abstract}
Instead of using energy to treat wastewater; it is actually feasible for one to harness energy from wastes as well as treating it using a Microbial Fuel Cell (MFC). An MFC generates electricity from sewage as well as sewage treatment in the same period. Four cells were used A, B, C and a control. The cells A, B, C all consisted of the anode and the cathode separated by a loamy-sandy soil of electricity conductivity, $160 \mu \mathrm{S}$ at $22.8^{\circ} \mathrm{C}$. The cathode and anodes were made of carbon rods obtained from A size dry cell. The anode and cathode were separated by 25 $\mathrm{mm}, 50 \mathrm{~mm}$ and $75 \mathrm{~mm}$ for cells $\mathrm{A}, \mathrm{B}$ and $C$ respectively. The control cell had no electrical components but shared the other components as those for cell $\mathrm{A}, \mathrm{B}$ and $\mathrm{C}$. sewage with COD of $2080 \mathrm{O}_{2} \mathrm{mg} / \mathrm{l}$ was introduced into the cell. Voltage and COD measurements were made every 24 hours and 10 days respectively to investigate performance. Laboratory measurements and recordings were made for 60 days and maximum voltages of $0.426 \mathrm{~V}, 0.261 \mathrm{~V}$ were recorded for $\mathrm{A}, \mathrm{B}$ and $\mathrm{C}$ respectively. The COD removal efficiencies were over $90 \%$, for $\mathrm{B}$ and $\mathrm{C}$; over $60 \%$ for $\mathrm{A}$ and less than $40 \%$ for the control even after 60 days. This asserted that MFCs generated electricity as well as being waste treatment devices than natural or constructed waste treatment ponds. Results also showed that the further the anode-cathode separation, the lower the voltage that was developed owing to increase in cell internal resistance. This paper furthers the potential to generate green and clean energy by means of an MFC.
\end{abstract}

Keywords: Sewage; Microbial fuel cell; Voltage; COD; Bacteria

\section{Introduction}

Due to continuous depletion of the fossil fuels and constant increase in the fuel's price, the world is moving towards the energy catastrophe [13]. However, consumption of fossil fuels causes an increase in pollution level which is a major cause of global warming [4]. So requisition of an alternate source of energy is increasing day by day which should be economical, reusable and cleans [5]. Therefore there is need to develop and improve on existing wastewater treatment technologies that are environmentally sustainable in these times of energy scarcity [6]. Studies show that energy can be extracted from organic wastewater as chemical energy or electric energy as well as treating the wastewater [7-9]. A MFC is a device which is used to generate electricity from wastewater with the help of micro-organisms [10]. A MFC consists of an anode and a cathode these compartments separated by a membrane like salt bridge [11-15]. There are two reactions that take place in an MFC, reduction and oxidation. Reduction in the anode compartment is due to the gain of electrons from the organic substrate [16-19]. The substrate is oxidized in the anode generating a proton and an electron [20]. The process of oxidation which is essence is decomposition is bio-catalyzed by bacteria. Bacteria gain energy by transferring these electrons from the substrate to the anode electrode [21]. The power output of an MFC is dependent on operational conditions and other factors like mass transfer and these factors influence the bio-reactor configurations. The operational factors that affect the power output of the bio-fuel cell are: $\mathrm{pH}$, temperature, concentration of dissolved oxygen and the electrolyte strength [22]. An MFC cannot attain maximum power output because of a number of factors that arise due to over potential related losses like ohmic concentration polarization and activation losses [23-25]. Over potential are resistances to the flow of electrons due to the flow path that the electrons take. The purpose of this study was produce electricity from sewage. In this study, four batch cells were used to determine the voltage developed by the MFC. The relationship between COD removal in wastewater and voltage produced by an MFC was also investigated to determine treatment efficiencies with respect to a control (cell without electrical components).

\section{Materials and Methods}

The materials used in the construction of the experimental cells A, $\mathrm{B}$ and C included: wastewater (sewage with initial COD of $2080 \mathrm{O}_{2} \mathrm{~g} /$ $\mathrm{ml}$ ) of $\mathrm{V}=880 \mathrm{ml}$, Carbon electrodes Sodium Chloride $(\mathrm{NaCl})$ solution, $0.6845 \mathrm{M}$, plastic cylinders $\mathrm{V}_{\mathrm{B}}=1000 \mathrm{ml}$; soil (sandy loam); Copper wire of $\mathrm{L}=7 \mathrm{~cm}$ attached to each electrode and plastic containers $\mathrm{V}_{\mathrm{s}}=125$ ml.(Figure 1)

\section{Constructing the cell experimental set up}

Four carbon electrodes were fastened to the $V_{B}$ container lids to make up the cathode. The $\mathrm{V}_{\mathrm{s}}$ containers were perforated at the bottom and at the sides to allow mass flow throughout the cell. Six negative electrodes (Anaerobic) were fastened together, and then fastened to the $\mathrm{V}_{\mathrm{s}}$ container using copper wire. The anode consisted of six carbon electrodes, four bundled together and the other two positioned five centimeters off the carbon bundle. The four were dipped into the loam soil and the two were fully dipped into the sewage. The Vs container was completely filled with loam soil covering the bundle of carbon electrodes in $\mathrm{V}_{\mathrm{s}}$. The $\mathrm{V}_{\mathrm{S}}$ container with its electrodes and soil were then, just fully immersed and fastened to the $\mathrm{V}_{\mathrm{B}}$ container. Sewage of COD $2080 \mathrm{O}_{2} \mathrm{mg} / \mathrm{l}$ was added to the cell assembly-which is housed by container $\mathrm{V}_{\mathrm{B}}$ - fully saturating the soil. Four cells were constructed; $\mathrm{A}, \mathrm{B}, \mathrm{C}$ and the control. The shortest distance of separation between the anode and the cathode was varied for the cells A, B and C. The

*Corresponding author: Anand Parkash, Department of Chemical Engineering Mehran University of Engineering \& Technology, Jamshoro, Pakistan, Tel: 0333796-2266; E-mail: parwani_anand@yahoo.com

Received July 05, 2015; Accepted July 23, 2015; Published July 27, 2015

Citation: Parkash A (2015) Generation of Bioenergy from Sewage Using Dual Chamber Microbial Fuel Cell. J Bioprocess Biotech 5: 242 doi:10.4172/2155 9821.1000242

Copyright: @ 2015 Parkash A. This is an open-access article distributed under the terms of the Creative Commons Attribution License, which permits unrestricted use, distribution, and reproduction in any medium, provided the original author and source are credited. 


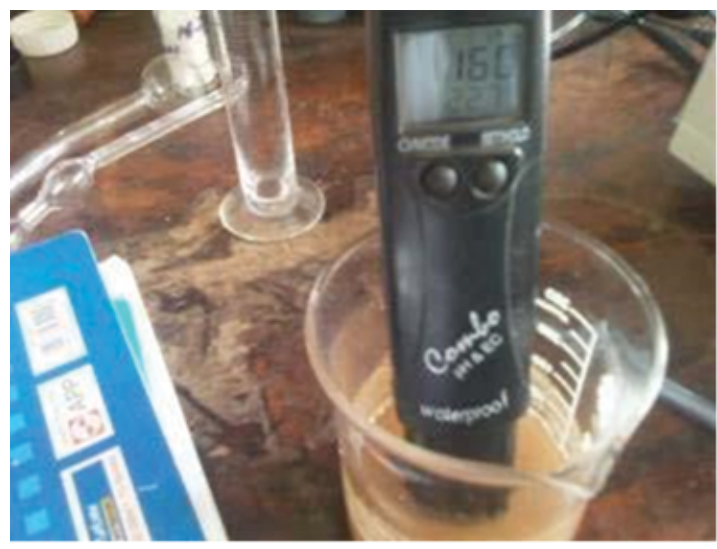

Figure 1: Electrical conductivity meter measuring the soil's E.C.

anode-cathode distance for $\mathrm{A}, \mathrm{B}$ and $\mathrm{C}$ were $25 \mathrm{~mm}, 50 \mathrm{~mm}$ and 75 $\mathrm{mm}$ respectively. The control cell consisted of all components in $\mathrm{A}, \mathrm{B}$ and $\mathrm{C}$ other than the electrodes and external circuit. Two milliliters of Sodium chloride solution $(0.6845 \mathrm{M})$ was added to A, B and C to increase electrical conductivity of sewage.

\section{Preparation of conductive solution (Sodium Chloride and Sewage Solution)}

Four grams of Sodium chloride were dissolved into $100 \mathrm{ml}$ of water to form a solution. Two milliliters of the solution were each added to cells A, B, C and the control.

\section{Determination of the electrical conductivity (E.C) of the soil to be used as a membrane}

Soil sample of $20 \mathrm{~g}$ was weighed and transferred to a beaker. Distilled water of $50 \mathrm{ml}$ was added to the beaker containing the soil sample. The soil-water mixture was stirred using a glass rod until a soil paste was attained. The mixture was then left to stand for 30 minutes. This allowed the soil to settle. The conductivity meter was then dipped in the upper portion of the separated mixture to measure soil E.C, pH and temperature as illustrated in Figure 1.

\section{Preparation of COD reagents}

COD reagent consists of standard Potassium dichromate and concentrated Sulphuric acid containing mercury Sulphate. The prepared reagents were to be used for the determining of COD levels in the cells A, B, C and the control.

\section{Standard potassium dichromate digestion solution}

Potassium dichromate of mass $4.913 \mathrm{~g}$ was dried at $103^{\circ} \mathrm{C}$ in an oven for two hours. The dried sample was then added to $500 \mathrm{ml}$ of distilled water. Concentrated Sulphuric acid of $167 \mathrm{ml}$ and $33.3 \mathrm{~g}$ of $\mathrm{Hg}_{2} \mathrm{SO}_{4}$ was then added to the dichromate solution. The mercury sulphate $\left(\mathrm{Hg}_{2} \mathrm{SO}_{4}\right)$ was added and the solution dissolved at room temperature. Distilled water of $100 \mathrm{ml}$ was added to the solution.

\section{Sulphuric acid reagent}

Dissolve $5.5 \mathrm{~g}$ of $\mathrm{Ag}_{2} \mathrm{SO}_{4}$ in a kilogram of $\mathrm{H}_{2} \mathrm{SO}_{4}$ and cool. The concentration of a kilogram of the concentrated acid was $16 \mathrm{M}$.

\section{Standard ferrous ammonium sulphate-0.05M}

Weighed $19.2 \mathrm{~g}$ of $\mathrm{Fe}\left(\mathrm{NH}_{3}\right)_{2}\left(\mathrm{SO}_{4}\right)_{2} \cdot 6 \mathrm{H}_{2} \mathrm{O}$ and immediately dissolved it in distilled water, ferrous Ammonium Sulphate is very unstable because it absorbs water from the atmosphere. Added $10 \mathrm{ml}$ of conc. $\mathrm{H}_{2} \mathrm{SO}_{4}$ to the ferrous solution; cooled and diluted to $1000 \mathrm{ml}$ (Figure 2).

\section{Preparation of COD digest samples}

Five COD test tube volumes of $15 \mathrm{ml}$ were cleaned with dilute $\mathrm{H}_{2} \mathrm{SO}_{4}$. The test tubes were oven dried for an hour. $0.5 \mathrm{ml}$ of sewage was transferred to each COD test tube. Standard Potassium dichromate and concentrated sulphuric acid (16 M) which were prepared earlier were then added in volumes of $2.5 \mathrm{ml}$ and $3.5 \mathrm{ml}$ respectively. The tubes were then capped, shook and cooled. The test tubes were then transferred into a COD digester and heated for 120 minutes at $150^{\circ} \mathrm{C}$. A blank, where distilled water was used instead of sewage and transferred to the digester to be the control for the COD test as shown in Figure 2.

\section{Measurement of voltage and resistance}

The measurement of voltage and resistance was done using a digital multimeter under the conditions; before agitating the cell and after agitating the cell. The readings were recorded every 20 seconds. The highest voltage and resistance readings in this interval were then recorded. After taking the reading for voltage and resistance of a given cell, the cell was then slowly agitated, whirling it (7 clockwise and 7 anticlockwise). This was done for the cells A, B and C. The voltage and resistance readings were taken for the cells in the same sequence as that done during the preliminary test period to measure the parameters for after agitation.

\section{Measurement of COD}

The digested samples were poured into a $50 \mathrm{ml}$ beaker. The beaker was then filled with distilled water up to the $50 \mathrm{ml}$ mark. The solution in the beaker was transferred into a flask and then three drops of Ferroin indicator were added turning the solution from red to orange. The digest solution in the flask was titrated against FAS solution. The solution turned to light green then colorless and finally to light red (red wine) at the end point. The burette reading was then recorded.

\section{Construction of practical model of an MFC}

A batch model of 18 liters was constructed to increase on the voltage to be generated. This model was constructed from projections of modifications that were to be made from the experimental cell designs of $\mathrm{A}, \mathrm{B}$ and $\mathrm{C}$. The modifications were based on the cell configurations that gave the highest voltage.

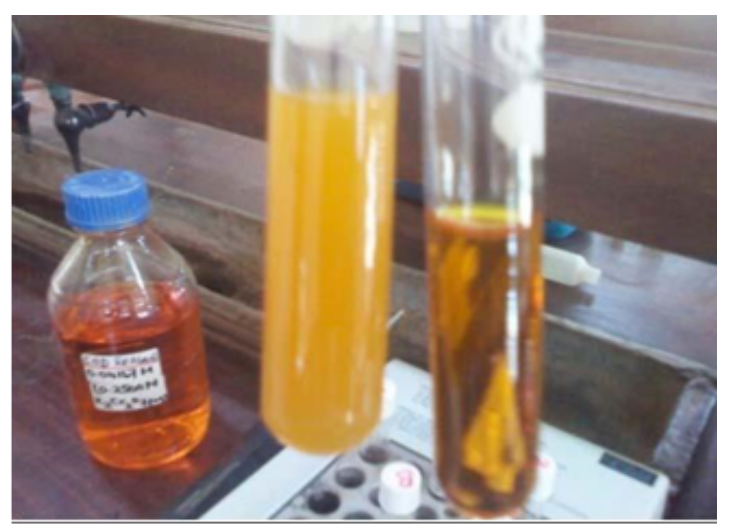

Figure 2: COD digest samples; the clear sample is the blank sample. 


\section{Results and Discussion}

\section{Voltage}

Voltage increased with time for reactors A, B and C (Figure 3). The Voltage for all the cells started with a slow increase and rose greatly after day 3. Cell A had a more steady increment in voltage from day three up to day nine. After day 9 to day 41, there was a slight change in voltage with time as compared to the earlier times. This slight variation in voltage took place at higher voltage. This same pattern in behavior was exhibited by cell B. Cell B exhibited a slightly constant voltage between day 17 and 35. Cell A's fall in voltage started after day 41 and continued steadily up to day 57 . Even though cell B exhibited the same behavior in voltage fall with time as $\mathrm{A}$, it on the other hand had a slight fall in voltage with time relative to $\mathrm{A}$. Cell $\mathrm{C}$ had a steady increment in voltage between day 1 and day 19. After day 19, C generally showcased a fall in voltage with a spike of high voltage rise at day 41 which was then followed with a sharp fall in voltage there after (Figure 3). In summary, the three cells A, B and C in Figure 3 exhibit three phases of voltage variation. The first is the voltage rise followed by steady voltage and lastly the voltage fall in the later part of the cell life. The agitated cells also showed the same behavioral trends but exhibited slightly higher voltage values for cell $\mathrm{A}$ and a fall in voltages for the cells $\mathrm{B}$ and $\mathrm{C}$ as shown in Figure 4.

\section{COD}

COD values for cells $A, B, C$ and the control generally fell with time as depicted in Figure 5. The fall in COD was steepest during the earlier times of the experimental set up between days 10 and 20. The COD fell from over 2000 to 1000 in about 30 days. Cells B and C continued the steady fall in COD through from days 20 to day 60. The fall in COD for $\mathrm{A}$, and the control cell were slightly lower relative to that of the cells $\mathrm{B}$ and $\mathrm{C}$.

The COD removal efficiency is the ratio of the difference between initial and final COD to initial COD. The COD removal efficiency for cells $\mathrm{B}$ and $\mathrm{C}$ was at a faster rate than that of the Control and cell $\mathrm{A}$ (Figure 6). The COD removal efficiency for the control cell was the least efficient. The COD removal efficiency for B and C reached $80 \%$ in less than 30 days of retention time. Cell $\mathrm{A}$ and the Control had treatment efficiencies of $58 \%$ and $30 \%$ respectively in the same period.

\section{Internal resistance of cells}

From Figure 7, the internal resistance for cells A, and B increases greatly during days 13 to 21 and then from 23 to 37 . Days 38 to 57 exhibited low internal resistances. There were abrupt increases in resistance for cells A and B on days 15, 17 and 21. Cell C then joined cells A and B in exhibiting spikes in resistance during days 29 to 33. But in general cell $\mathrm{C}$ had low internal resistance compared to the cells $\mathrm{A}$ and $\mathrm{B}$. Figure 8 shows a general increase of internal resistance exhibited by all the cells that is A, B and C between day 1 through today 6. Cells A and $B$ generally exhibited higher values of internal resistance compared to cell $\mathrm{C}$ between days 15 and 40 . Cell $\mathrm{C}$ exhibited the lowest values in general for resistance on the logarithmic scale.

\section{Discussion}

Generally, voltage for all the cells A, B and C are divided into three phases; the voltage rise, stationary and fall phase (as shown in Figure 3). The voltage rise phase consists of two stages that is the early stage (days 0-3) and advanced volt-age rise stage (days 4-9). The early stage has lower voltage change gradients than advanced voltage. During the early stage, voltage growth is slow because of three reasons: low bacteria population and the bacteria are trying to acclimatize to the cell environment; presence of high concentration of electron acceptors; limited colonization of the anode surface by bacteria. For this reason during the early stage, every time agitation was done on the cells a foul smell was expelled from the cells (as Equation 1). The degree of the stench decreased with time from day $0-3$. On day 4 , there was no more

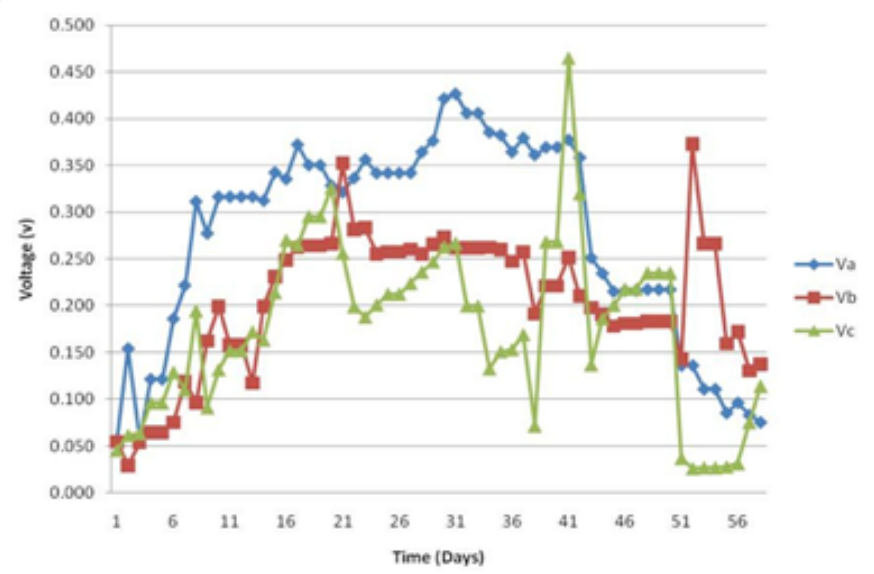

Figure 3: Voltage generation against time for cells $A, B$ and $C$.

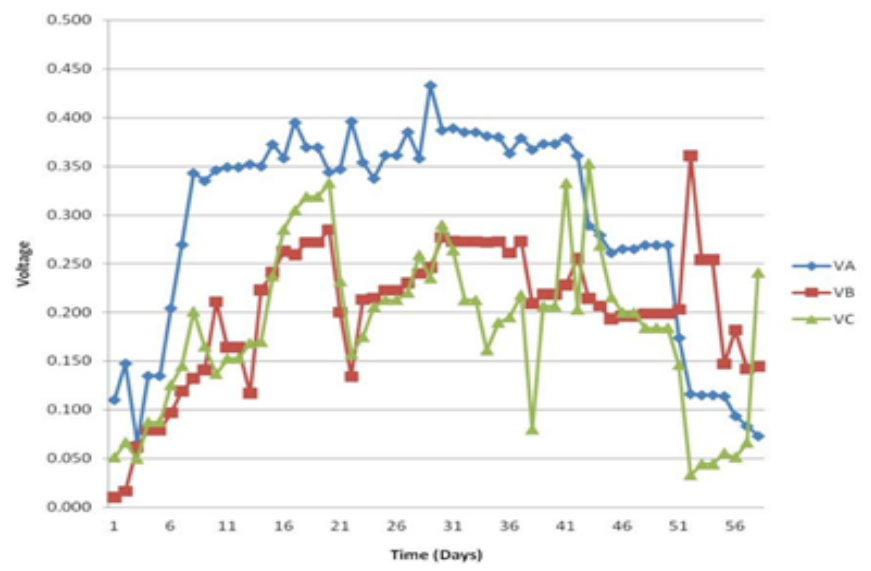

Figure 4: Voltage generation against time for cells $A, B$ and $C$ after agitation.

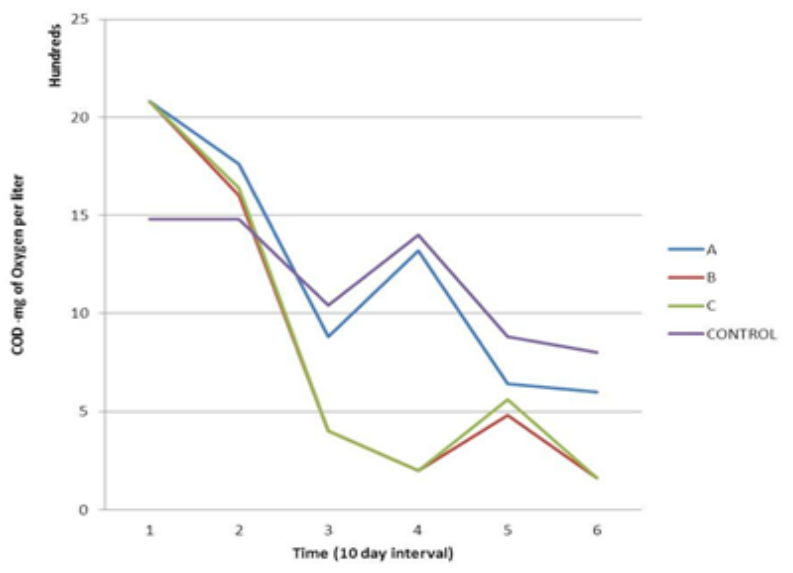

Figure 5: COD against time (10 days interval) for cells A, B, C and the control. 


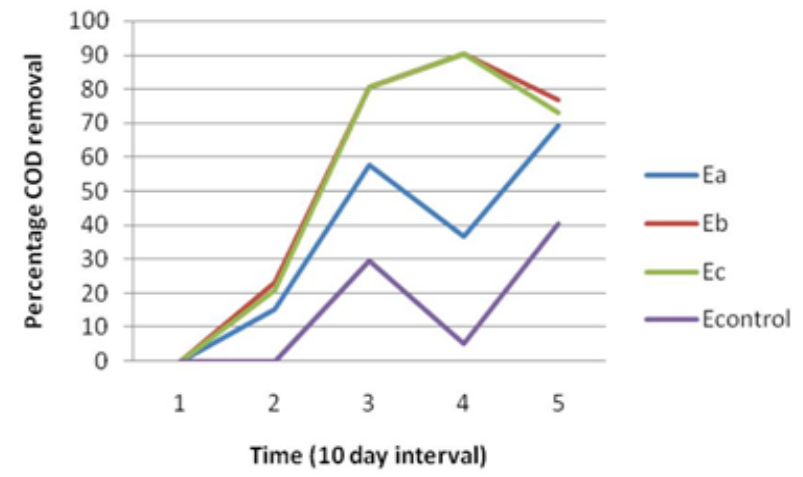

Figure 6: Removal efficiency for cells A, B, C and the control.

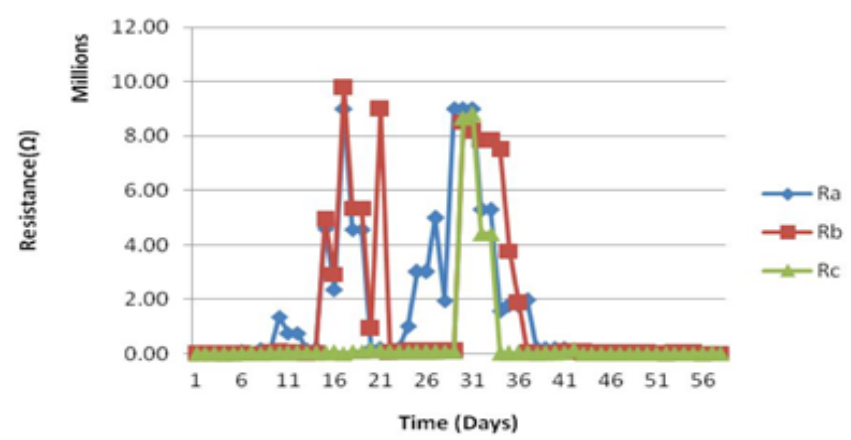

Figure 7: Removal efficiency for cells A, B, C and the control.

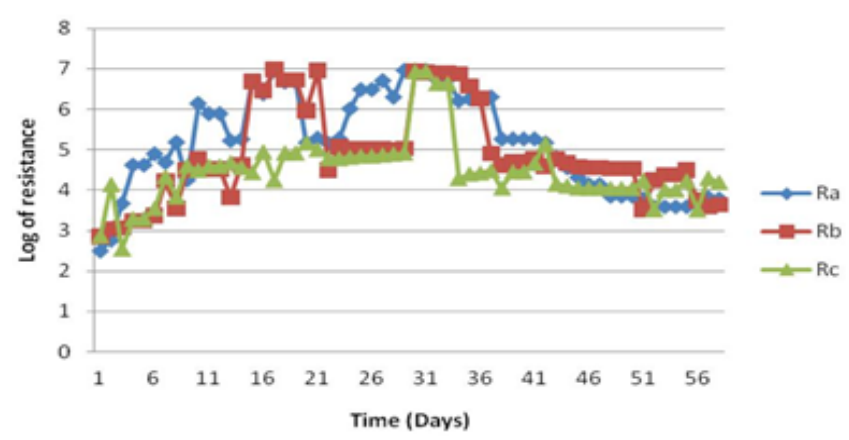

Figure 8: Internal resistance against time (days) for cells A, B and C.

smell which meant that there was a low concentration of sulphates in sewage which is similar to similar observations by.

$$
\mathrm{SO}_{4}^{2-}+10 \mathrm{H}^{+}+8 \mathrm{e} \longrightarrow 4 \mathrm{H}_{2} \mathrm{O}+\mathrm{H}_{2} \mathrm{~S}
$$

During the advanced voltage rise stage, there was an in-crease in the bacteria community responsible for the generation of voltage. The steady increase is a factor which is also increased by the bacterial community forming a film/colonizing the anode surface. The stationary phase is of maximum constant voltage. Since the voltage developed entirely depends on bacteria community responsible for voltage development between the anode and cathode; the voltage at this phase is constant since the bacterial community responsible for voltage development is at a constant population. The constant population signifies that the number of bacteria dying is equal to the number that is being reproduced. During this stage, the food available can only sustain a constant bacterial population. The constant population was the maximum achievable population by the bacterial com-munity in correspondence with the available food. The last stage of voltage change is the voltage fall phase. It is between days 42 and 58 (Figure 3). This was due to the fall in COD or food for the bacteria as shown in Figure 5. This would have led to a great fall in bacteria community due to decrease in food quantity [3]. The trend of voltage change that has been discussed above is analogous to the bacteria growth curve. Bacteria growth curve consists of four growth phases, that is; the lag phase, exponential phase, stationary phase and the death phase. The lag and exponential phase correlate to the voltage rise phase. The stationary and voltage fall phases correlate to the stationary and death phase respectively.

\section{Phase B (exponential phase) and C stationary phase and voltage variation}

If $S(t)$ denotes the concentration of substrate/ nutrient in the media and $\mathrm{N}(\mathrm{t})$ denotes concentration of bacteria at time $\mathrm{t}$. Bacteria reproduce by fission. A fully grown bacterium reproduces by dividing into two equal daughter cells. Each daughter cell would then grow and further divide into two for each daughter cell making four cells.

The Malthusian's Equation model:

$\frac{\mathrm{dN}(\mathrm{t})}{\mathrm{dt}}=\mathrm{kN}(\mathrm{t})$

$\mathrm{K}$ - Growth rate constant and $\mathrm{K}>0$

$\int \frac{\mathrm{dN}(\mathrm{t})}{\mathrm{N}(\mathrm{t})}=\mathrm{kdt}$

$\mathrm{N}(\mathrm{t})=\mathrm{Ae}^{\mathrm{kt}}$

Since the change in the concentration of bacteria is assumed to be proportional to the change in voltage, then equation 2.1 becomes 2.2 :

$\mathrm{V}(\mathrm{t})=\mathrm{V}(0) \mathrm{e}^{\mathrm{kt}}$

$\mathrm{V}(\mathrm{t})$-voltage at time $\mathrm{t}$ and $\mathrm{V}(0)$ voltage at time $\mathrm{t}=0$.

But the bacteria growth is best explained using the Jacques Monod model that factors the nutrient parameter $\mathrm{S}(\mathrm{t})$ into the equation. The Jacques Monod model equation (3.0) is an improvement of the Malthusian model equation (Equation 2.0).

$$
\frac{\mathrm{dN}(\mathrm{t})}{\mathrm{N}(\mathrm{t}) \mathrm{dt}}=\frac{\mathrm{rS}(\mathrm{t})}{\mathrm{a}+\mathrm{S}(\mathrm{t})}
$$

r-Maximum growth rate and a-half saturation constant But COD/ nutrient $(\mathrm{S}(\mathrm{t})$ ) was depicted to be reducing with time (Figure 5) Monod also found that the rate of nutrient (COD) was opposite in sign to bacteria growth but proportional to it:

$$
\gamma \frac{\mathrm{dS}(\mathrm{t})}{\mathrm{dt}}=-\frac{\mathrm{dN}(\mathrm{t})}{\mathrm{dt}}
$$

Where $\gamma$ - growth yield constant combining equations 3.0 and 3.1:

$$
\begin{aligned}
& \gamma \frac{\mathrm{dS}(\mathrm{t})}{\mathrm{dt}}=-\mathrm{N}(\mathrm{t}) \frac{\mathrm{rS}(\mathrm{t})}{\mathrm{a}+\mathrm{S}(\mathrm{t})} \\
& \text { At } \mathrm{t}=0, \mathrm{~S}(0)=\mathrm{S} \text { and } \mathrm{N}(0)=\mathrm{N}
\end{aligned}
$$

Equation 3.1 is the same as:

$$
\gamma \frac{\mathrm{dS}(\mathrm{t})}{\mathrm{dt}}+\frac{\mathrm{dN}(\mathrm{t})}{\mathrm{dt}}=0
$$




$$
\mathrm{S}(\mathrm{t})=\mathrm{S}+\frac{\mathrm{N}(\mathrm{t})-\mathrm{N}}{\gamma}
$$

To obtain an expression for bacteria population, $\mathrm{N}(\mathrm{t})$ :

$$
\frac{\mathrm{dN}(\mathrm{t})}{\mathrm{dt}}=\mathrm{rN}\left[\frac{\gamma \mathrm{S}+\mathrm{N}(\mathrm{t})-\mathrm{N}}{\gamma \mathrm{a}+\gamma \mathrm{S}+\mathrm{N}(\mathrm{t})-\mathrm{N}}\right]
$$

The expression for change in bacteria population is similar to change in voltage since voltage production is a factor of bacteria action on the existing substrate $\mathrm{S}(\mathrm{t})$. Notice that at the stationary phase of bacteria growth, the rate of change

$$
0=\mathrm{eN}(\mathrm{t})\left[\frac{\gamma \mathrm{s}+\mathrm{N}(\mathrm{t})-\mathrm{N}}{\gamma \mathrm{a}+\gamma \mathrm{S}+\mathrm{N}(\mathrm{t})-\mathrm{N}}\right]
$$

\section{Solution is $N(t)=0$ and $N(t)=N-\gamma S$.}

This means that at the time when the rate of change bacteria growth (voltage) is zero, either bacterial population (voltage) is zero the population (voltage) change is constant and is being kept constant by the existing nutrient concentration, $S$.

Equation 3.3 can be approximated to be equivalent to (with a voltage relationship):

$$
\frac{\mathrm{dV}(\mathrm{t})}{\mathrm{dt}}=\varphi \mathrm{V}(\mathrm{t})\left[\frac{\gamma \mathrm{S}+\mathrm{V}(\mathrm{t})-\mathrm{V}}{\gamma \mathrm{a}+\gamma \mathrm{S}+\mathrm{V}(\mathrm{t})-\mathrm{V}}\right]
$$

$\varphi$ - This is a constant of proportionality that relates voltage and bacterial population.

Cell A, with an anode-cathode separation $25 \mathrm{~mm}$ developed greater voltage between its electrodes because of small distance in comparison to the other cells that is $\mathrm{B}(50 \mathrm{~mm})$ and $\mathrm{C}(75 \mathrm{~mm})$. The distance between the cathode and anode determines the speed with which the electrons are going to travel between the soil layer and therefore the shorter the distance in a given time, the faster the current and therefore the higher the voltage. This is similar to results by [23]. From ohms law, voltage is directly proportional current therefore the voltage would also increase. Voltage was slightly enhanced on agitation of cell fuel contents (Figure 4) Agitation ensured evenness in the distribution of biodegradable material in the cells. The evenness made the material easily accessible for voltage generation by the bacteria population on the anode electrode surface.

\section{Internal resistance}

Internal resistance of the cells generally increased with time (Figure 8). Since ions are responsible for conductivity in the cells then the increase in resistance must be attributed to the decrease in electricity conducting shuttles/carriers [12]. The electricity conducting shuttles present in sew-age include sulphate ions, nitrates, nitrites, ammonium, sulphides, hydrogen ions, phosphates and other salt ions. The concentration of ions like the sulphates, nitrites, nitrates and others were reduced since they are electron acceptors. The sulphate is reduced to sulphide and then given off to the atmosphere as hydrogen sulphide which exhibits an undesirable odor. This odor is given out in high concentration during the first three days of cell life. The nitrates and nitrites are also given off to the atmosphere through the nitrogen cycle. The process of electron acceptor loss led to the decrease in concentration of the ions in the three cells. This led to the decrease in the concentration of conducting ions leaving just the sodium and chloride ions as the ions responsible for conductivity in the cells. The internal resistance also further increased because of loss of water from the soil which was used as the proton ex-change membrane. Initially the soil is saturated with the sewage sample and the conductivity of the soil is higher than $160 \mathrm{~S}$ at $22.8^{\circ} \mathrm{C}$ (Table 1). The ions responsible for conductivity at this point are those contained in the soil, the added sodium chloride and the salts contained in the sewage. When the soil moisture content decreased, this meant that the migration of ions across the soil membrane from the anode to the cathode became more difficult. Resistance was highest during the times of low moisture content and the resistance greatly varied with moisture content. It was expected that the internal resistance would in-crease with time but this was not the case (Figure 8). During the early times of ion migration across the soil towards the cathode compartment, there was slow accumulation of ions in the soil (membrane). This accumulation of ions led to an increase in the ion concentration thus an increase in E.C. The increase in ion concentration by far surpasses the effect of moisture content variation. This led to an increase of E.C of the cells or a decrease in electrical resistance of the cells. The E.C increased from $160 \mathrm{~S}$ on day 0 to $243 \mathrm{mS}$ on day 55 (Table 1).

\section{Conclusion}

The experimental data obtained showed that it is actually possible to generate electric power from the waste water. The distance between the cells' anode and cathode deter-mined the magnitude of the voltage created between the electrodes. The shorter the distance between the anode and the cathode, the higher the voltage developed between the electrodes. Using soil as a membrane greatly increased the cell's internal resistance therefore the use of soil is not viable option for electricity generation. The MFC cells showed higher treatment efficiency rates than ordinary waste treatment ponds under similar environmental conditions (Figure 6). The highest treatment efficiency was $80 \%$ after 20 days whereas that of the control was $30 \%$ after the same number of days. The constructed practical model developed a maximum volt-age of about $217 \mathrm{mV}$ on day one from the introduction of the MFC fuel.

\section{Recommendations}

The voltage generated was still low and coupled with a high internal resistance lowered the power generated by the cells. The following are the possible studies and changes that should be established to enhance an MFC's power rating:

- The electrical conductivity of the MFC fuel solution should be enhanced to levels that do not affect the bacterial community in the sewage/waste as well as to levels that lower the cell's internal resistance to acceptable levels. Electrical conductivity can be increased by increasing on the concentration of electrolytes in the fuel solutions. The concentration of the ions can affect the metabolism of bacterium in the MFC fuel.

- Studies on voltage and resistance changes should also be carried out at an hourly or half-hour basis to get a better view of the variation of voltage with time.

- Studies should be carried out to establish the most appropriate $\mathrm{C} / \mathrm{N}$ ratio that gives off the highest electrical voltage. Further studies

\begin{tabular}{|c|c|c|c|}
\hline Day & E.C $(\mathbf{m S})$ & $\mathbf{p H}$ & Temperature $\left.\mathbf{~}^{\circ} \mathbf{C}\right)$ \\
\hline 0 & 0.160 & 5.8 & 22.8 \\
\hline 55 & 243 & 6.1 & 21.5 \\
\hline
\end{tabular}

Table 1: Soil Electrical Conductivity. 
can also be made through co-digestion of several biodegradable materials to establish which materials will give the highest voltage from the cell.

- Applying of genetic engineering in the development of strains of bacteria that will be highly adaptive, efficient in the breakdown of the bio material as well as have a high affinity for a variety of bio material

- Up scaling of the MFC to larger treatment volumes like septic tanks and industrial food processing waste ponds and with further development, designs should be made that incorporate MFC into waste water treatment plants.

\section{Acknowledgement}

The authors wish to express their sincere thanks for the lab facilities provided for this work in the Department of Chemical Engineering, Mehran University of Engineering and Technology, Jamshoro.

\section{References}

1. Chang IS, Kim BH, Lovitt RW, Bang JS (2001) Effect of CO partial pressure on cell-recycled continuous CO fermentation by Eubacterium limosum KIST612. Process Biochem 37: 411-421.

2. Chang IS, Jang JK, Gil GC, Kim M, Kim HJ, et al. (2004) Continuous determination of biochemical oxygen demand using microbial fuel cell type biosensor. Biosens Bioelectron 19: 607-613.

3. Chang IS, Moon H, Jang JK, Kim BH (2005) Improvement of a microbia fuel cell performance as a BOD sensor using respiratory inhibitors. Biosens Bioelectron 20: 1856-1859.

4. Cheng X, Shi Z, Glass N, Zhang L, Zhang J, et al. (2004) A review of PEM hydrogen fuel cell contamination: Impacts, mechanisms, and mitigation. $J$ Power Sources 165: 739-765.

5. Gong M, Liu X, Trembly J, Johnson C (2007) Sulfur-tolerant anode materials for solid oxide fuel cell application. J Power Sources 168: 289-298.

6. Kim IS, Chae KJ, Choi MJ, Verstraete W (2008) Microbial fuel cells: recent advances, bacterial communities and application beyond electricity generation. Environ Eng Res 13: 51-65.

7. Kim JR, Min B, Logan BE (2005) Evaluation of procedures to acclimate a microbial fuel cell for electricity production. Appl Microbiol Biotechnol 68: 23-30.

8. Lee J, Phung NT, Chang IS, Kim BH, Sung HC (2003) Use of acetate for enrichment of electrochemically active microorganisms and their 16S rDNA analyses. FEMS Microbiol Lett 223: 185-191.

9. Liu H, Cheng S, Logan BE (2005) Production of electricity from acetate or butyrate using a single-chamber microbial fuel cell. Environ Sci Technol 39: 658-662.
10. Pham TH, Jang JK, Chang IS, Kim BH (2008) Improvement of cathode reaction of a mediatorless microbial fuel cell. J Microbiol Biotechnol 14: 324-329.

11. Ragauskas AJ, Williams CK, Davison BH, Britovsek G, Cairney J, et al. (2006) The path forward for biofuels and biomaterials. Science 311: 484-489.

12. Gil GC, Chang IS, Kim BH, Kim M, Jang JK, et al. (2003) Operationa parameters affecting the performannce of a mediator-less microbial fuel cell. Biosens Bioelectron 18: 327-334.

13. Song C (2008) Fuel processing for low-temperature and high-temperature fue cells: Challenges and opportunities for sustainable development in the $21 \mathrm{st}$ century. Catal Today 77: 17-49.

14. Aelterman P, Rabaey K, Pham HT, Boon N, Verstraete W (2006) Continuous electricity generation at high voltages and currents using stacked microbial fue cells. Environ Sci Technol 40: 3388-3394.

15. He Z, Minteer SD, Angenent LT (2005) Electricity generation from artificial wastewater using an upflow microbial fuel cell. Environ Sci Technol 39: 52625267.

16. Liu H, Logan BE (2004) Electricity generation using an air-cathode single chamber microbial fuel cell in the presence and absence of a proton exchange membrane. Environ Sci Technol 38: 4040-4046.

17. Rabaey K, Clauwaert P, Aelterman P, Verstraete W (2005) Tubular microbia fuel cells for efficient electricity generation. Environ Sci Technol 39: 8077-8082.

18. Schröder U, Niessen J, Scholz F (2003) A generation of microbial fuel cells with current outputs boosted by more than one order of magnitude. Angew Chem Int Ed Engl 42: 2880-2883

19. You S, Zhao Q, Zhang J (2006) A microbial fuel cell using permanganate as a cathodic electron acceptor J Power Sources 162: 1409-1415.

20. You S, Zhao Q, Zhang J (2006) A graphite-granule membrane-less tubular aircathode microbial fuel cell for power generation under continuously operational conditions. J Power Sources 173: 172-177.

21. Jiansheng H, Ping Y, Yong G, Zhang K (2011) Electricity generation during wastewater treatment: An approach using an AFB-MFC for alcohol distillery wastewater. Desalination 276: 373-378.

22. Oh ST, Kim JR, Premier GC, Lee TH, Kim C, et al. (2010) Sustainable wastewater treatment: how might microbial fuel cells contribute. Biotechno Adv 28: 871-881.

23. Du Z, Li H, Gu T (2007) A state of the art review on microbial fuel cells: A promising technology for wastewater treatment and bioenergy. Biotechnol Adv 25: 464-482.

24. Zhao F, Harnisch F, Schroder U (2006) Application of pyrolysed iron (II) phthalocyanine and CoTMPP based oxygen reduction catalysts as cathode materials in microbial fuel cells. Biotechnol Lett 30: 1771-1776.

25. You SJ (2005) Identification of denitrifying bacteria diversity in an activated sludge system by using nitrite reductase genes. Biotechnol Lett 27: 1477-1482. 